overseas Governments. As a consequence, he has travelled widely and has first-hand knowledge of mining conditions in many parts of the world, which, coupled with his research experience, will prove to be of particular value to the Royal School of Mines while building up the traditions of the new Department-a Department the work of which is devoted to one of those fascinating areas to be found lying between pure science on one hand and conventional engineering on the other, and which only now are beginning to be investigated systematically.

\section{The National Institute of Agricultural Botany : Dr. P. S. Wellington, D.S.C.}

DR. P. S. WELLINGToN has been appointed assistant director of the National Institute of Agricultural Botany as from July 1, 1961. The vacancy was caused by the death of Mr. G. W. G. Briggs (Nature, $190,861 ; 1961)$. Since 1952, Dr. Wellington has been the chief officer of the Official Seed Testing Station for England and Wales, which is one of the branches of the Institute. In this position he has been responsible for statutory tests under the Seeds Act and has initiated a programme of investigations into the problems arising from new methods of handling and conditioning the seed of farm and garden crops. Dr. Wellington is a graduate of the University of Londan, where he obtained first-class honours in botany at the Royal College of Science (Imperial College). During the War he served as an observer in the Fleet Air Arm and was awarded the D.S.C. in 1941.

International Meteorological Organization Prize for 1961: $\quad$ Prof. K. R. Ramanathan

Prof. K. R. Ramanathan, of the Physical Research Laboratory, Ahmedabad, has been awarded the International Meteorological Organization Prize for outstanding work in meteorology and international collaboration. Prof. Ramanathan studied at Victoria College, Palghat, and Presidency College, Madras, and after obtaining a doctor's degree in science, he became a demonstrator in physics at Trivandrum College and later a research scholar at the University of Madras. In 1922 he joined Rangoon University College as a lecturer in physics. In 1925 he became a member of the Indian Meteorological Department. After having been director of the Kodaikanal and Bombay Observatories, he was appointed deputy director-general of observatories. In 1948 he was appointed director of the Physical Research Laboratory in Ahmedabad. Prof. Ramanathan has worked on problems of molecular scattering of light in fluids, atmospheric and solar radiation, study of the Indian monsoon, general circulation of the atmosphere, atmospheric ozone, physics of the ionosphere and aeronomy. For several years he was the president of the International Union of Geodesy and Geophysics, and was also president of the International Association of Meteorology of that Union. He has been, and still is, the president of the International Ozone Commission. The International Meteorological Organization Prize was established in 1955 by the World Meteorological Organization in honour of the former non-Governmental organization which had initiated international collaboration in meteorology in 1878, but which ceased in 1951 when the World Meteorological Organization took over. The Prize consists of a gold medal and 1,200 U.S. dollars.

\section{Taxation of Scientific Bodies}

ON the second reading of the Rating and Valuation Bill in the House of Lords on May 31 the position of the scientific societies was strongly represented by the Earl of Halsbury, the Earl of Cranbrook and Lord Douglas of Barloch, though Earl Jellicoe had not mentioned this question in moving the second reading. Lord Hailsham, in replying on the debate, said that there is a prospect of fairly general agreement between the Government and the learned societies about the way in which the problem should be tackled (see Nature, May 20, p. 657). He referred again to the deputation he had received on behalf of the societies, but repeated that he did not think it would be right to deal with the question within the scope of the present Bill beyond the 50 per cent mandatory relief. It would not be right to ask local authorities to undertake what was fundamentally a national burden. Lord Hailsham said that he recognized to the full what Lord Halsbury and Lord Cranbrook had said about the value of the work of these societies, that many of them are essential to the working of science, that they produce publications and maintain libraries of national importance, but his own opinion was that the difficulty could not be dealt with by rate relief at all, but that it must be dealt with by grants in some form. He thought we should consider using the Royal Society and the British Academy as vehicles for this kind of negotiation, and if they were prepared to act the Government would be glad to hear from them as and when the situation developed.

\section{United Kingdom-Euratom Technical Collaboration}

IN a written answer in the House of Commons on June 6, the Parliamentary Secretary for Science, Mr. D. Freeth, said that co-operation under the United Kingdom-Euratom Technical Collaboration Agreement had covered a wide range of subjects. These included basic reactor physics, reactor planning and programming, reactor economics and the costing of nuclear power, fast reactors and gas-cooled reactors, thermonuclear fusion, nuclear measurements, mass spectrometry, workshop organization, health and safety, corrosion, the construction of 'hot' laboratories, the industrial applications of radioisotopes, juridical problems arising from nuclear ship propulsion, radiation protection and third-party liability. Co-operation had proceeded by exchange of reports, visits of experts, conferences and symposia, and attachment of staff to specific projects and establishments. The United Kingdom also collaborated with Euratom and the United States Atomic Energy Commission in the translation pool "Transaitom", which concentrated on translations from Russian and Japanese.

\section{Funds for Cotton, Silk and Man-Made Fibres Research}

The Cotton Industry Development Council (Amendment No. 4) Order, 1961, which was approved by the House of Commons on May 8, enables the Cotton Board to collect a statutory levy from firms processing man-made fibres, to support the British Cotton, Silk and Man-Made Fibres Research Association, which is being formed by the merging of the British Cotton Industry Research Association and the British Rayon Research Association, as recommended last year in the report of the working-party appointed by the Councils of the two Associations (see Nature, 